\title{
INISIASI TUNAS RAMIN MELAUI KULTUR JARINGAN
}

Shoots initiation of Gonystylus bancanus Kurz In-vitro Propagation

\author{
Jayusman dan Arif Setiawan \\ Pusat Litbang Hutan Tanaman
}

\begin{abstract}
A study on the preliminary research of tissue culture on Gonystylus bancanus Kurz has been done with the objectives of determining: (1) basal media and (2) combination of plant growth regulator suitable for culturing in vitro. The large scale can provide a way to mass produce within a short time bulk quantity of good quality seedlings of good breeding parental trees. Evaluationwas done using four basal media (Murashige and Skoogs (MS); 1/2 MS; Woody Plant Medium (WPM) and Greshoff \& Doys)(GD). Two auxin plant growth regulators: Indole Acetic Acid (IAA), Napthalene Acetic Acid (NAA) and Cytokinin (Benzyl Amino Purine-BAP) of varying concentration, either alone or in combination were evaluated in the shoot tip culture. The results indicated that shoot tip explant planted in $1 / 2$ basal media with combination of BAP 1ppm + NAA 0.01 ppm gave the best response on initiation of explant shoot. While GD media with combination BAP $1.25 \mathrm{ppm}+$ IAA $0.05 \mathrm{ppm}$ seemed suitable only for callus induction which growth was poor.
\end{abstract}

Keywords: Gonystylus bancanus Kurz, plant growth regulator, shoot tip, tissue culture.

\begin{abstract}
ABSTRAK
Penelitian inisiasi tunas ramin (Gonystylus bancanus) melalui perbanyakan kultur jaringan telah dilakukan dengan obyek pengamatan meliputi (1) media dasar dan (2) kombinasi zat pengatur tumbuh (zpt) yang sesuai untuk kultur jaringan G. bancanus. Pada skala luas diharapkan dapat menyediakan bibit skala produksi masal dalam waktu singkat dengan kualitas bibit sesuai induknya. Pengujian dilakukan dengan berbagai media dasar yaitu Murashige and Skoogs (MS); 1/2 MS; Woody Plant Medium (WPM) dan Greshoff \& Doys (GD). Dua jenis Auxin: Indole Acetic Acid (IAA), Napthalene Acetic Acid (NAA) dan jenis Sitokinin (Benzyl Amino Purine-BAP) pada berbagai konsentrasi, kombinasi beberapa zat pengatur tumbuh akan diuji dalam kultur tunas ramin ini. Hasil pengujian menunjukkan bahwa eksplan yang ditanam pada media 1/2 media dasar dengan kombinasi BAP 1 ppm + NAA 0,01 ppm, terbukti memberikan respon terbaik pada inisiasi tunas. Media GD dengan BAP 1,25 ppm + IAA 0,05 ppm terlihat hanya sesuai untuk induksi kalus dengan perkembangan lambat.
\end{abstract}

Kata kunci: Gonystylus bancanus, kultur jaringan, kultur tunas, zat pengatur tumbuh. 


\section{PENDAHULUAN}

Ramin termasuk famili Thymelaceae dan bermarga Gonystylus memiliki sebaran yang cukup luas mulai dari Indonesia, Malysia, Philipina, hingga kepulauan Solomon, Nicobar dan Fiji. Jumlah species diperkirakan mencapai 30 jenis yaitu 27 jenis ditemukan di Kalimantan utamanya di Serawak dan Semenanjung Peninsula, 7 jenis di Sumatra dan 2 jenis di Philipina. Species dari marga Gonystylus yang banyak dikenal adalah Gonystylus bancanus dan $G$. macrophyllus. Kayu ramin memiliki keunggulan antara lain bentuk fisik bagus, kayu ringan dengan tekstur halus. Produk yang dihasilkan umumnya berbentuk kayu olahan (sawn timber), produk setengah jadi (moulding, dowels) dan produk jadi (furniture, window blinds dan snooker cues). Negara tujuan ekspor produk kayu ramin ke Italia, Amerika Serikat, Taiwan, Jepang, Cina dản Inggris. Kayu ramin telah menjadi primadona di pasar kayu internasional dengan harga cukup tinggi yaitu sebesar 1000 dollar AS per $\mathrm{m}^{3}$ (Forest Watch Indonesia, 2002). Potensi tersebut malah menjadi bencana bagi eksistensi kayu ramin sendiri, setelah menjadi andalan perusahaan HPH hutan rawa tahun 1990-an, dalam beberapa tahun ini menjadi incaran aktivitas illegal logging, dampaknya adalah keterancaman dan kepunahan ramin, sehingga pemerintah Indonesia memasukkan kayu ramin ke dalam Appendix II CITES - Convention on International Trade in Endangerred Species of Wild Fauna and Flora (UNEP-WPMC, 2005).

Umumnya fenologi ramin belum banyak diketahui. Benih ramin sulit diperoleh karena fenologinya tidak menentu dan dilaporkan berbunga dan berbuah 4 - 5 tahun sekali (Jayusman, et al, 2003). Karakter ini sangat menyulitkan kegiatan penyiapan bahan tanaman (bibit). Berbagai upaya pemenuhan bibit telah dirintis seperti teknik cabutan anakan alam dan vegetatif makro, namun belum memuaskan hasilnya. Untuk itu teknik kultur jaringan perlu diuji yang dapat menjadi alternatif kegiatan penyiapan bahan tanaman maupun untuk tujuan konservasi aseptik. Berkaitan dengan metoda konservasi aseptik, maka integrasi bank kultur jaringan (ex-situ konservasi) ke dalam upaya konservasi jenis ramin layak dipertimbangkan karena memiliki beberapa keunggulan (Graudal et al, 1997) meliputi keuntungan dan kendala teknik konservasi statis (ex-situ) (a) membutuhkan ruang yang relatif sempit, (b) mampu mengurangi erosi genetik apabila menggunakan metoda cryopreservation, (c) sesuai untuk benih rekalsitran maupun benih ortodok serta material hasil perbanyakan vegetatif, (d) variasi intra-inter populasi dapat diselamatkan sesuai sampel yang tersedia, (e) merupakan konservasi aseptik (meminimalisir kerusakan karena penyakit) dan (f) waktu yang dibutuhkan untuk menghasilkan propagul adalah relatif singkat. Mengawali kegiatan tersebut maka penguasaan protokol kultur jaringan ramin menjadi penting untuk dilakukan secepatnya. Tujuan utama penelitian ini adalah merintis pemantapan kultur in-vitro guna mendukung pembangunan konservasi aseptik jenis ramin melalui penapisan awal kultur in-vitro meliputi (1) teknik penyiapan eksplan dan teknik sterilisasi yang sesuai dalam kultur jaringan G. bancanus dan (b) mendapatkan medium dasar dan kombinasi jenis dan konsentrasi zat pengatur tumbuh yang optimum dalam kultur jaringan G. bancanus. 


\section{BAHAN DAN METODE}

\section{A. Waktu dan Tempat}

Penclitian propagasi mikro ramin dilaksanakan di laboratorium kultur jaringan Pusat Penelitian dan Pengembangan Hutan Tanaman (P3HT) Purwobinangun, Yogyakarta. Waktu yang dibutuhkan untuk menyelesaikan penelitian ini selama 10 bulan mulai Desember 2004 sampai dengan September 2005. Penelitian dilaksanakan untuk menguji media dasar dan variasi kombinasi zat pengatur tumbuh (ZPT) terhadap pertumbuhan eksplan tunas ramin.

\section{B. Bahan Penelitian}

\section{Eksplan (tunas)}

Tunas yang digunakan dalam penelitian diambil dari semai hasil cksplorasi berupa cabutan anakan alam dan stek di Propinsi Riau dan Kalimantan Tengah yang pra-kondisi awal sumber eksplan tersebut dilakukan di rumah kaca laboratorium kultur jaringan P3HT, Kaliurang, Yogyakarta. Tunas baru yang muncul dari Stek dan cabutan anakan setelah tiga bulan merupakan bahan eksplan dalam pengujian ini seperti disajikan pada Gambar 1 .
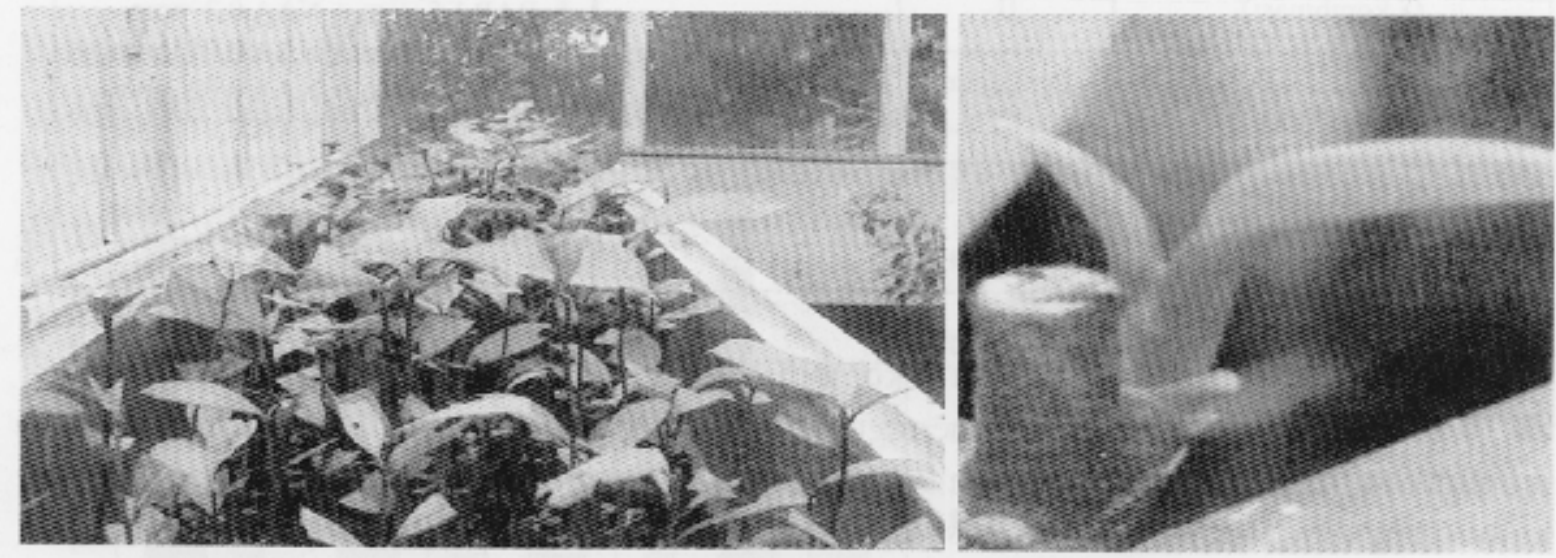

Gambar 1. Scmai sumber eksplan ramin (G. bancants) tahap pra-kondisi di rumah kaca.

\section{Media dasar}

Media dasar yang dipergunakan adalah Murashige dan Skoog (MS dan 1/2 MS), Woody Plant Medium (WPM) dan Greshoff \& Doys (GD), serta kombinasi ZPT Auxin (NAANafthalena Acetid Acid dan IAA-Indole Acetid Acid) serta Sitokinin (BAP-Benzyl Amino Purine) dengan berbagai konsentrasi terhadap induksi tunas G. bancanus.

\section{Sterilisasi Eksplan}

Untuk mendapatkan bahan yang steril, tunas-tunas dari semai ramin di semprot terlebih dahulu dengan fungisida I hari sebelum digunakan, kemudian eksplan dibersihkan dengan kuas dan kapas pada air mengalir, direndam larutan fungisida \pm 20 menit, direndam larutan cairan pencuci sunlight \pm 20 menit dan direndam dalam larutan alkohol $70 \%$ selama 30 detik. Eksplan dibawa ke Laminar Air Flow Cabinet untuk strerilisasi lanjutan dengan larutan 
sunclean $1 \%$ selama 1 menit sebanyak 2 kali dan dibilas dengan aquadest steril sampai bersih dan selanjutnya siap untuk tanam dalam media kultur. Eksplan selesai ditanam kemudian diletakan didalam rak media dan disimpan dalam ruang kultur dengan pengaturan suhu dan kelembaban.

\section{Rancangan Penelitian}

Penelitian di rancang secara Rancangan Acak Lengkap non-faktorial dengan fokus menguji berbagai medium dasar dan kombinasi ZPT dalam berbagai konsentrasi. Kombinasi perlakuan yang diuji dalam penelitian disajikan pada Tabel 1.

Tabel 1. Kombinasi medium dasar dan konsentrasi ZPT pada tahap induksi G. bancanus.

\begin{tabular}{|c|c|c|c|}
\hline Kode Perlakuan & Optimasi & $\begin{array}{c}\text { Medium Dasar } \\
\text { (M) }\end{array}$ & $\begin{array}{c}\text { Jenis dan Kombinasi ZPT } \\
(\mathrm{ZK})\end{array}$ \\
\hline $\begin{array}{c}\text { M1ZK1 .......M1ZK8 } \\
\text { (8 kombinasi) }\end{array}$ & $\begin{array}{c}\text { Pengujian } \\
\text { I }\end{array}$ & MS & \multirow{4}{*}{$\begin{array}{l}\text { 1. BAP } 2,0 \mathrm{ppm}+\text { IAA } 0,02 \mathrm{ppm} \\
\text { 2. BAP } 1,25 \mathrm{ppm} \text { + IAA } 0,05 \mathrm{ppm} \\
\text { 3. BAP } 0,25 \mathrm{ppm} \text { + IAA } 0,15 \mathrm{ppm} \\
\text { 4. BAP } 1,0 \mathrm{ppm} \text { + IAA } 0,01 \mathrm{ppm} \\
\text { 5. BAP } 1,5 \mathrm{ppm} \text { + NAA } 0,2 \mathrm{ppm} \\
\text { 6. BAP } 2,0 \mathrm{ppm} \text { + NAA } 0,01 \mathrm{ppm} \\
\text { 7. BAP } 2,0 \mathrm{ppm} \text { + NAA } 0,02 \mathrm{ppm} \\
\text { 8. BAP } 0,5 \mathrm{ppm} \text { + NAA } 0,01 \mathrm{ppm}\end{array}$} \\
\hline $\begin{array}{c}\text { M2ZK1 .......M2ZK8 } \\
\text { (8 kombinasi) }\end{array}$ & $\begin{array}{l}\text { Pengujian } \\
\text { II }\end{array}$ & $1 / 2 \mathrm{MS}$ & \\
\hline $\begin{array}{c}\text { M3ZK } 1 \text {.......M3ZK } 8 \\
\text { (8 kombinasi) }\end{array}$ & $\begin{array}{l}\text { Pengujian } \\
\text { III }\end{array}$ & WPM & \\
\hline $\begin{array}{c}\text { M4ZK1 .......M4ZK8 } 8 \\
\text { (8 kombinasi) }\end{array}$ & $\begin{array}{l}\text { Pengujian } \\
\text { IV }\end{array}$ & GD & \\
\hline
\end{tabular}

Setiap pengujian menggunakan 8 kombinasi (yaitu 1 medium dasar dan 8 konsentrasi ZPT) dan setiap unit perlakuan menggunakan 10 sampel (eksplan), total eksplan yang dibutuhkan untuk pengujian adalah 320 eksplan. Parameter utama adalah respon eksplan kultur yang dinilai dengan skoring (score) sebagai berikut : (a) nilai $0=$ eksplan kontaminasi, (b) nilai $1=$ ekplan mati, (c) nilai $2=$ tidak ada respon, (d) nilai $3=$ eksplan berkalus dan (e) nilai 4 = bertunas. Data yang diperoleh dianalisis menggunakan analisis varians, apabila terdapat beda nyata data dianalisis lebih lanjut menggunakan prosedur Uji Duncan (Least Significant Range Test).

\section{HASIL DAN PEMBAHASAN}

\section{A. Hasil Penelitian}

Pengamatan terhadap induksi eksplan yang membentuk kalus dan tunas secara morfologis disajikan pada Gambar 2. 

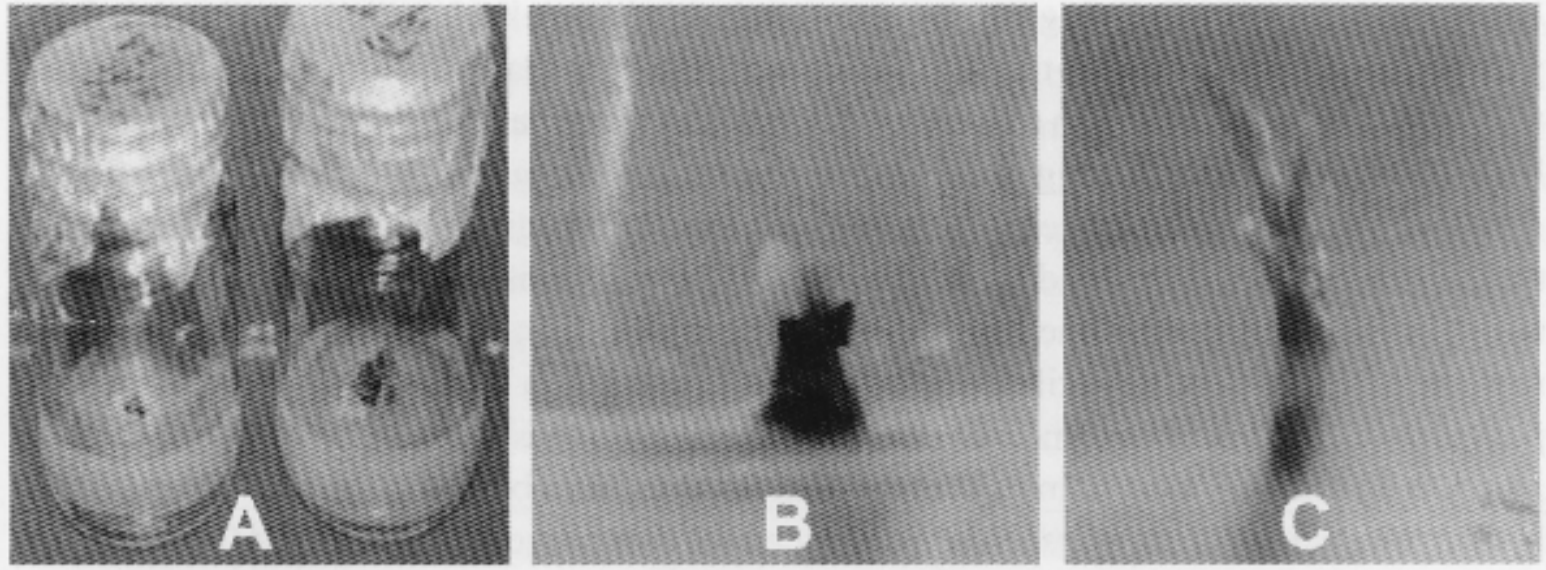

Gambar 2. Tahap induksi tunas G. bancanus, kalus (A) dan perkembangan induksi tunas (B dan C).

Gambar 2 memperlihatkan bahwa sebagian eksplan tahap induksi merespon dengan berbagai karakter seperti berkalus (A) dan bertunas (B dan C). Hasil ke empat pengujian dibuat ringkasan dalam bentuk histogram dan hasilnya disajikan pada Gambar 3.

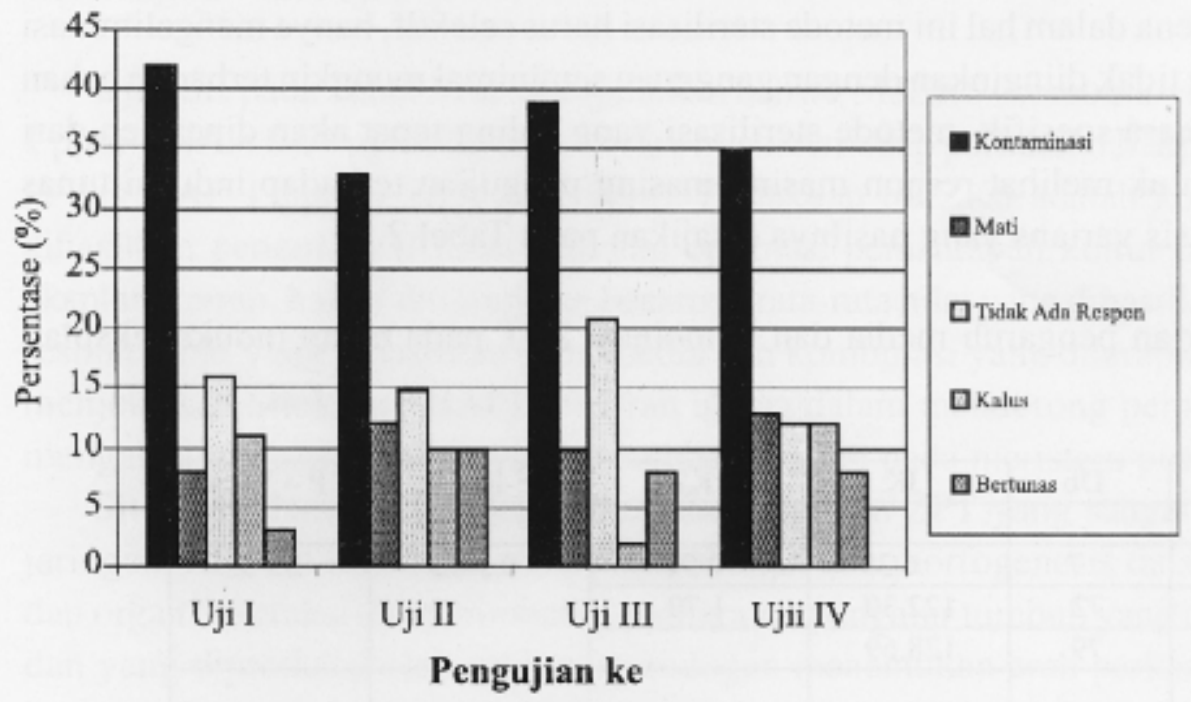

Gambar 3. Histogram pengaruh kombinasi media kultur dan konsentrasi ZPT pada fase induksi eksplan jenis G. bancanus.

\section{B. Pembahasan}

Hasil pengujian menunjukkan bahwa persentase kontaminasi berkisar 33\% - 42\% dan eksplan mati berkisar $8 \%-13 \%$, eksplan pasif (tidak merespon) $12 \%-21 \%$, eksplan berkalus $2 \%-12 \%$ dan $3 \%-10 \%$. Tingginya tingkat kontaminasi eksplan pada penelitian ini, analog apa yang dilaporkan oleh Sopiana (2004) pada eksplan daun ramin. Gamborg and Shyluk (1981) menjelaskan bahwa faktor penting yang berperan dalam budidaya in-vitro adalah eksplan dan kandungan nutrien (salah satunya ZPT). Ditambahkan oleh Wetherell (1982) 
bahwa kemampuan suatu bagian tanaman untuk dijadikan eksplan dipengaruhi oleh 3 hal yaitu kemampuan regenerasi, tingkat fisiologi dan kesehatan dari tanaman itu sendiri. Tingkat fisiologi berhubungan dengan totipotensi dan setiap sel tanaman mempunyai totipotensi yang berbeda (Pierik, 1987). Penggunaan eksplan pucuk G. bancanus dalam penelitian ini pada dasarnya sudah tepat karena eksplan tersebut merupakan bagian jaringan muda dan mudah tumbuh (meristem), apabila ada penambahan ZPT dengan konsentrasi yang tepat pada media tanam maka akan dapat mendorong pertumbuhan tunas. Setiap jenis tanaman akan menghendaki perlakuan sterilisasi yang berbeda, meskipun teknik yang diterapkan pada pengujian eksplan ramin ini mengacu teknik yang telah berhasil untuk jenis Santalum album maupun Tectona grandis, namun keberhasilan tahap inisiasi belum maksimal. Eksplan mati kemungkinan tidak tahan terhadap zat kimia tersebut karena menurut Gunawan (1987) bahanbahan sterilisasi ini umumnya bersifat toxic (racun) terhadap jaringan tanaman. Eksplan yang mati akibat keracunan dapat menyebabkan kontaminasi pada permukaan media.

Media dasar yang mampu relatif cepat dan peka terhadap kontaminasi dari sumber eksplan dan teknik sterilisasi yang berbeda-beda pada umumnya adalah media $1 / 2$ MS dan MS. Hal ini disebabkan karena konsentrasi penyusun bahan dasar media pada media MS lebih tinggi dibandingkan dengan GD. Umumnya media yang mengandung gula, vitamin dan mineral dengan konsentrasi tinggi maka cendawan dan bakteri akan tumbuh secara cepat. Gunawan (1987) menjelaskan dari semua sumber kontaminan, maka kontaminan dari eksplan yang paling sulit diatasi karena dalam hal ini metode sterilisasi harus selektif, hanya mengeliminasi organisme mikro yang tidak diinginkan dengan gangguan seminimal mungkin terhadap bahan tanaman, sehingga secara spesifik, metode sterilisasi yang paling tepat akan diperoleh dari kegiatan optimasi. Untuk melihat respon masing-masing pengujian terhadap induksi tunas ramin dilakukan analisis varians yang hasilnya disajikan pada Tabel 2.

Tabel 2. Analisis varian pengaruh media dan kombinasi ZPT pada tahap induksi eksplan ramin.

\begin{tabular}{|c|c|c|c|c|c|}
\hline Sumber Variasi & $\mathrm{Db}$ & JK & $\mathrm{KT}$ & F-Hitung & $P$-Value \\
\hline \multicolumn{6}{|l|}{ Pengujian I } \\
\hline Perlakuan & 7 & 6.39 & 0.91 & \multirow[t]{3}{*}{$0.54 \mathrm{~ns}$} & \multirow[t]{3}{*}{0.804} \\
\hline Galat & 72 & 122.30 & 1.70 & & \\
\hline Total & 79 & 128.69 & & & \\
\hline \multicolumn{6}{|l|}{ Pengujian II } \\
\hline Perlakuan & 7 & 29.40 & 4.20 & \multirow[t]{3}{*}{$2.23^{*}$} & \multirow[t]{3}{*}{0.042} \\
\hline Galat & 72 & 135.80 & 1.89 & & \\
\hline Total & 79 & 165.20 & & & \\
\hline \multicolumn{6}{|l|}{ Pengujian III } \\
\hline Perlakuan & 7 & 4.89 & 0.70 & \multirow[t]{3}{*}{$0.35 \mathrm{~ns}$} & \multirow[t]{3}{*}{0.926} \\
\hline Galat & 72 & 142.50 & 1.98 & & \\
\hline Total & 79 & 147.39 & & & \\
\hline \multicolumn{6}{|l|}{ Pengujian IV } \\
\hline Perlakuan & 7 & 2.69 & 0.38 & \multirow[t]{3}{*}{$0.18 \mathrm{~ns}$} & \multirow[t]{3}{*}{0.989} \\
\hline Galat & 72 & 156.50 & 2.17 & & \\
\hline Total & 79 & 159.19 & & & \\
\hline
\end{tabular}

Keterangan: $*=$ berbeda nyata pada taraf uji 0,01

ns = tidak berbeda nyata 
Analisis varian tahap induksi pada Tabel 1, menunjukkan bahwa pengujian II menunjukkan hasil berbeda nyata, sedangkan pengujian lainnya tidak berbeda nyata. Pengujian II menghasilkan rata-rata eksplan bertunas terbesar dibandingkan yang lain. Faktor media yang diuji dan kombinasi ZPT yang diaplikasikan pada tahap induksi eksplan ramin ini secara keseluruhan belum optimal, hal ini didukung respon eksplan yang relatif rendah. Untuk melihat perbedaan antar perlakuan yang berpengaruh nyata dilakukan uji LSR (Least Significant Range Test), yang hasil selengkapnya disajikan pada Tabel 3.

Tabel 3. Uji LSR bentuk media dan kombinasi zpt dalam induksi eksplan ramin.

\begin{tabular}{|c|c|c|c|}
\hline Media dan kombinasi ZPT & N & Nilai Rata-rata & Notasi (pengelompokan) \\
\hline M2ZK8 & 10 & 26 & $\mathrm{a}$ \\
M2ZK1 & 10 & 21 & $\mathrm{ab}$ \\
M2ZK2 & 10 & 16 & $\mathrm{abc}$ \\
M2ZK6 & 10 & 12 & abcd \\
M2ZK3 & 10 & 10 & abcde \\
M2ZK5 & 10 & 10 & abcdef \\
M2ZK7 & 10 & 9 & abcdefg \\
M2ZK4 & 10 & 8 & bcdefgh \\
\hline
\end{tabular}

Keterangan : taraf uji $5 \%$

Uji LSR pada Tabel 3 memperlihatkan bahwa M2ZK8 (kombinasi media 1/2 MS dan BAP $1 \mathrm{ppm}+$ NAA 0,01 ppm) berbeda secara nyata terhadap perlakuan M2ZK4 (kombinasi media $1 / 2$ dan BAP $1 \mathrm{ppm}+$ IAA 0,01 ppm). Perlakuan M2ZK8 adalah kombinasi terbaik yang dihasilkan pengujian II pada kegiatan optimasi pemantapan kultur jaringan tahap induksi eksplan Ramin, hal ini ditunjukkan besarnya rata-rata nilai yang dihasilkan dan perkembangan respon tunas yang dihasilkan pada media dan kombinasi yang diterapkan. Wattimena (1988) menjelaskan Sitokinin (BAP) berperan utama dalam mendorong pembelahan sel dan dapat mengatasi masalah rendahnya laju pembelahan sel pada meristem pucuk.

Sitokinin dan Auksin merupakan dua golongan ZPT yang sangat penting dalam kultur jaringan. ZPT ini mempengaruhi pertumbuhan dan morfogenesis dalam kultur sel, jaringan dan organ. Interaksi dan perimbangan antara zat pengatur tumbuh yang diberikan dalam media dan yang diproduksi oleh sel secara endogen menentukan arah perkembangan suatu kultur. Penambahan auksin atau sitokinin eksogen mengubah level ZPT endogen sel. Level ZPT endogen ini kemudian merupakan trigerring factor untuk proses-proses yang tumbuh dan morfogenesis (Gunawan, 1987). BAP dalam konsentrasi tinggi (1mg/l $10 \mathrm{mg} / 1$ ) dapat menginduksi tunas (Pierik, 1987). Sedang menurut Hartman et al, (1990), BAP biasa digunakan dengan konsentrasi antara $0,01 \mathrm{mg} / 110 \mathrm{mg} / \mathrm{l}$ dan NAA digunakan dengan konsentrasi antara $0,1 \mathrm{mg} 10 \mathrm{mg} / 1$. NAA $10 \mathrm{mg}$ umumnya digunakan pada konsentrasi antara 0,01 sedangkan BAP dengan konsentrasi berkisar antara $0,110 \mathrm{mg} / \mathrm{l}$.

Pada percobaan I - IV memperlihatkan bahwa medium 1/2 MS memberikan rata rata pertumbuhan tunas yang terbaik dibandingkan dengan medium MS, WPM dan GD, hal ini didukung oleh respon eksplan dan perkembangan maupun pertumbuhan eksplan yang dihasilkan. Namun demikian, perkembangan dan pertumbuhan tunas ramin dikategorikan sangat lambat, sehingga dikawatirkan akan menjadi kendala pada tahap multiplikasi nantinya. 
Ditambahkan oleh Sopiana (2004) bahwa dengan menggunakan eksplan daun $G$. bancanus pada media WPM padat dengan penambahan NAA dan kinetin hanya mampu menginisiasi kalus tetapi perkembangan kalus tidak sampai menjadi organ tanaman sampai 12 minggu setelah kultur. Setiap bentuk eksplan dan jenis tanaman menghendaki perlakuan kombinasi zat pengatur tumbuh yang berbeda sebagaimana pengujian yang dilaporkan oleh Astuti (2005) melalui aplikasi $3 \mathrm{mg} / \mathrm{l}$ BAP sudah sesuai untuk tahap induksi tunas Acacia mangium dengan eksplan tunas dari cabang atas, pengujian kombinasi NAA $0 \mathrm{mg} / \mathrm{l}$ dan BAP $1 \mathrm{mg} / \mathrm{l}$ sesuai untuk memacu pembentukan tunas Santalum album (Sari, 2004), pengujian kombinasi BAP $0,5 \mathrm{mg} / \mathrm{l}+$ Kinetin $0,2 \mathrm{mg} / \mathrm{l}$ sesuai untuk multiplikasi tunas dari eksplan kecambah Eucalyptus pellita (Nurcahyaningsih dan Sapulete, 2000) serta aplikasi kombinasi ZPT BAP 1,5 mg/l + NAA $0,025 \mathrm{mg} / \mathrm{l}$ terbukti efektif untuk mendapatkan jumlah tunas optimal pada inisiasi tunas Gmelina arborea (Wulandari, 2002).

Zat pengatur tumbuh NAA dan BAP berpengaruh sangat nyata terhadap pembentukan jumlah tunas. Ini berarti tunas yang terbentuk dipengaruhi oleh keseimbangan antara NAA dan BAP. Pembentukan tunas dipengaruhi oleh sitokinin (BAP), karena hormon ini berpengaruh terhadap pembelahan sel, pembesaran sel dan merangsang diferensiasi tunas (Wilkins, 1989). Abidin (1982) dan Zimmerman (1985) menjelaskan bawa dalam pertumbuhan jaringan, Sitokinin berpengaruh terutama pada pembelahan sel, bersama sama dengan Auksin memberikan pengaruh interaksi terhadap diferensiasi jaringan. Ditambahkan oleh Hussey dalam Katuuk (1989) bahwa konsentrasi Sitokinin yang lebih tinggi dari Auksin akan mendorong ke pembentukan tunas sedangkan konsentrasi Auksin relatif tinggi daripada sitokinin akan mendorong ke pembentukan akar. Model ini tidak selalu berlaku untuk seluruh spesies tanaman, karena selain tingkat kandungan Sitokinin atau Auksin endogen berbeda untuk setiap spesies tanaman maupun tahap pertumbuhannya dan juga karena adanya faktor faktor lain terhadap kemampuan organ dan jaringan dalam regenerasi tunas atau akar. Pertimbangan aspek ini akan menjadi perhatian utama terhadap pemantapan kultur G. bancanus tahap lanjut.

\section{KESIMPULAN}

1. Kegiatan penapisan kultur in-vitro dengan menguji bentuk media dan kombinasi jenis dan konsentrasi ZPT menunjukkan bahwa, faktor pembatas teknik in-vitro jenis ramin adalah tingginya kontaminasi dan pertumbuhan tunas yang lambat.

2. Hasil inisiasi tunas ramin menunjukkan bahwa eksplan pucuk dari semai cabutan anakan alam yang dipra-kondisi di rumah kaca sebagai sumber eksplan dan ditanam pada media kultur 1/2 MS dengan aplikasi kombinasi BAP 1 ppm + NAA 0,01 ppm, terbukti memberikan respon terbaik pada inisisasi tunas, sedangkan media GD dengan aplikasi kombinasi ZPT BAP 1,25 ppm + IAA 0,05 ppm terlihat hanya sesuai untuk induksi kalus dengan perkembangan lambat. 


\section{DAFTAR PUSTAKA}

Abidin, Z., 1982. Dasar Dasar Pengetahuan Tentang Zat Pengatur Tumbuh. Penerbit Angkasa; Bandung.

Astuti, I, 2005. Pengaruh Takaran Sitokinin Terhadap Keberhasilan Induksi Tunas dan Adenin Sulfat Terhadap Perbanyakan Tunas Acacia mangium WILLD Dengan Teknik Kultur Jaringan. Skripsi Fahutan UGM, 2005. 59 halaman (tidak dipublikasikan).

Forest Watch Indonesia, 2003. Kondisi Hutan Indonesia. Forest Watch Indonesia, 2004. Ramin Oh Ramin. Sebuah Catatan Hasil Studi Perdagangan Domestik dan International Kayu Ramin di Indonesia. http://fwi.or.id/Kondisi Hutan/Data/Tutupan Hutan 2003. htm. 7/ 12/2004. Gamborg, O.L. and J.P. Shylluk. 1981. Nutrition Media and Characteristic of Plant Cell and Tissue Culture.

Gamborg, DL and J.P. Shylluk, 1981. Nutrition Media and Characteristic of Plant Cell and Tissue Culture. Method and Application in Agriculiure.ed. THORPE.T. Academic Press New York - London - Sydney - San Francisco.

Graudal, L. E. Kjaer, A Thomsen and A.B Larsen, 1997. Planning National Programmes for Conservation of Forest Genetic Resources. Danida Forest Seed Centre. Technocal note 48. Pp 36.

Gunawan, L.W. 1987. Teknik Kultur Jaringan. Laboratorium Kultur Jaringan Tanaman Pusat Antar Universitas (PAU) Bioteknologi Institut Pertanian Bogor.

Hartman, T., D. E. Kester, and F. T. Davies, 1990. Plant Propagation: Principles and Practices. Prentice Hall, Inc, New Jersey.

Jayusman, SL Tobing, E Kuato, 2003. Duka Dibalik Musnahnya Tegakan Gonystylus bancanus Kurtz Di Hutan Teluk Kiambang. Warta Balai Litbang Kehutanan Sumatera. Vol 4, 2003.

Katuuk, P. R. J., 1989, Teknik Kultur jaringain dalam Mikropopagasi Tanaman. Proyek Pengembangan Lembaga Pendidikan Tenaga Kependidikan, Jakarta.

Nurcahyaningsih, ILG dan E. Sapulete, 2000. Perbanyakan Eucalyptus pellita Secara Kultur Jaringan. Bulletin Penelitian Pemuliaan Pohon Volume 4 (1) 2000 P3BPTH Yogyakarta. Halaman 25 - 37.

Pierik, I. L. M. 1987. In Vitro Culture Of Higher Plant. Martinus Nijhoff Publisher, Netherland.

Sari, E.A, 2004. Optimasi Pembentukan Tunas Acacia mangium dengan Perlakuan Variasi Hormon NAA dan BAP Serta Variasi Umur Eksplan. Skripsi fakultas Biologi Universitas Kristen Duta Wacana (tidak dipublikasikan).

Sopiana, R. 2004. Pembentukan Kalus dan Organogenesis Daun Ramin (G. bancanus) dengan Penambahan NAA dan Kinetin pada Woody Plant Medium. Skripsi Fakultas Pertanian Universitas Sriwijaya. Palembang. 
UNEP WCMC. 2005. Species Database of Gonystylus bancanus (Miq.) Kurz. Document URL Query Date: 18 September 2005.

Wattimena, G.A. 1988. Zat Pengatur Tumbuh Tanaman. PAU X Bioteknologi X IPB dan LS1, Bogor. 145.

Wetherell, D. F. 1982. Pengantar Propagasi Tanaman Secara In-Vitro (Terjemahan). IKIP Semarang Press, Semarang.

Wilkins, M. B., 1989. Fisiologi Tanaman (Terjemahan). Penerbit PT. Bina Aksara, Jakarta.

Wulandari R S, 2002. Pengaruh Pemberian Auxin dan Sitokinin Terhadap Pertumbuhan Eksplan Kultur Jaringan Pada Gmelina arborea Linn. Tesis Program Pasca Sarjana Universitas Gadjah Mada. 63 halaman (tidak dipublikasikan).

Zimmerman, R. H. 1985. Application of Tissue Culture Propagation to Woody Plants. In (R. R. Henke and K. W. Hughes). Tissue Culture in Forestry and Agriculture. Plenum Press. New York. pp : 238.

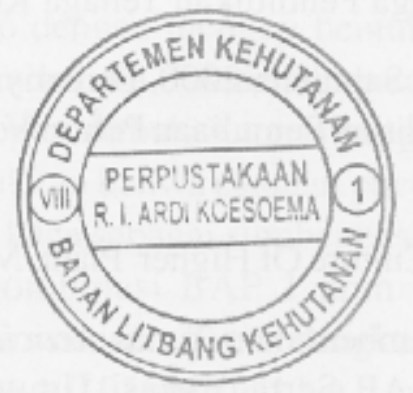

